a very few coarse moist râles as on the occasion of the first examination. The sputum was examined almost every day for three weeks but no tubercle bacilli could be found. Several guinea-pigs were also inoculated again with negative results. The expectoration, especially when much blood was present, was teeming with spirochætæ. The saliva and superficial scrapings from the gums were also examined; some spirochætæ were present but always in small numbers.

The second case was that of a male Indian. He presented symptoms similar to those of the first case; he had chronic cough with hæmorrhagic expectoration; also occasional attacks of hæmoptysis when a certain quantity of pure blood was spat up. According to the patient there had never been any fever and he had not wasted. He was extremely nervous ; in fact, he had become neurasthenic, thinking he was suffering from pulmonary tuberculosis. The physical examination of the chest showed only a few coarse moist râles on coughing in the lower part of both lungs. The sputum never contained tubercle bacilli and the guinea-pigs inoculated remained healthy. Spirochætæ were always present in great numbers, especially when blood and muco-pus were present in large amount. Spirochætæ could be found also in the saliva and scrapings from the gums but only in small numbers.

The spirochætæ were always very numerous and stained well by the Leishman method, generally taking up a bluish tint; they could be stained also with the ordinary aniline dyes, though not so well. They were generally mixed with some bacteria, but sometimes when the sputum was collected in sterile Petri dishes and preparations made at once they were practically the only germs present. Vincent's fusiform bacilli were never observed. These spirochætæ were not all alike. They might be divided morphologically into several groups. 1. Very thick individually, from 15 to 30 microns in length, with irregular waves which varied in number but were never very numerous. The parasites, with the Leishman method, stained deep blue; they were pointed at both ends. 2. Spirochætæ resembling the spirochæta refringens (Schaudinn) with a few graceful waves and pointed extremities. 3. Thin, delicate spirochætæ with numerous small, rather uniform waves and tapering ends. Sometimes one of the extremities was blunt while the other was pointed. 4. Very delicate parasites, though thicker than the spirochæta pallida, with very few waves generally irregular in shape.

All the types I have briefly described may be seen in tbe illustration. Similar types may be found, according to my

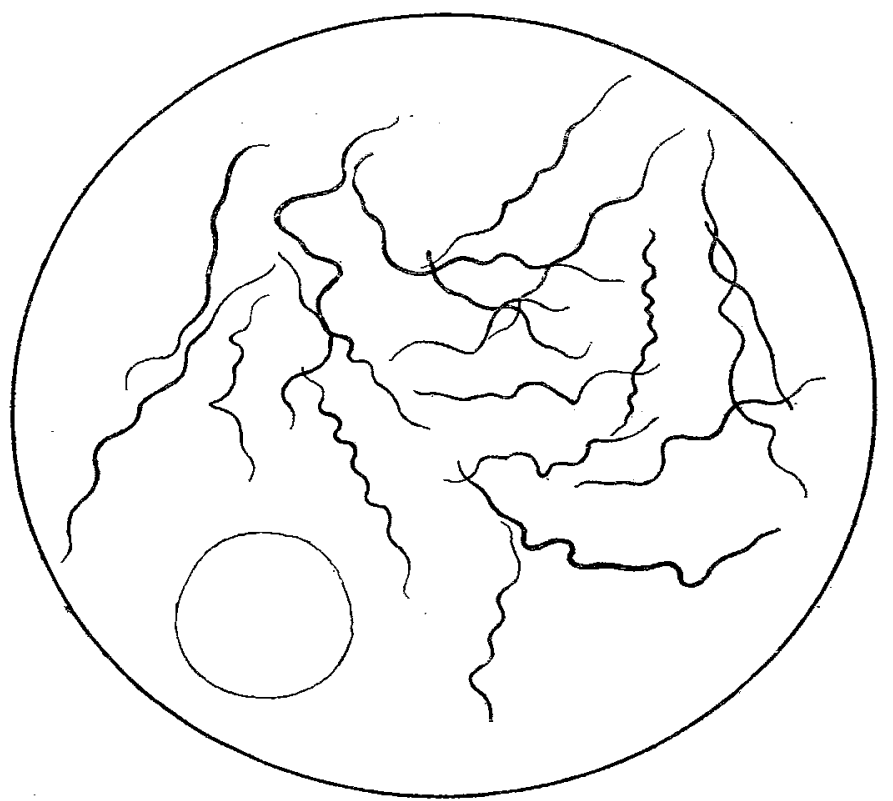

Showing the various forms of spirochætæ observed.

experience, also in spirochætæ observed in the mouth; it might be, therefore, that I had to deal with a bronchial or broncho-alveolar localisation of the spirochæta buccalis, which term, there is no doubt, covers many varieties of spirochætæ.

These two cases of hæmorrhagic bronchitis are of an obscure nature; it seems to me that they cannot be considered of a tuberculous origin. The microscopical examination excludes the possibility of a form of endemic hæmoptysis from distomum Ringeri. It might be suggested, perhaps, that possibly the spirochætæ present in such large numbers in the expectoration-sometimes practically without other germs-may have had a part in the etiology of the complaint. It is interesting to note that Plimmer has noticed in guinea-pigs a peculiar form of pseudo-tuberculosis and that in the smears taken from the pseudo-tuberculous lesions he found numerous spirochætæ.

Colombo.

\section{HYPERTROPHY AND DILATATION OF THE HEART IN A CHILD WITHOUT VALVULAR DISEASE OR GENERAL ADHESION OF THE PERI- CARDIUM.'}

By GEORGE CARPENTER, M.D. LOND., M.R.C.P. LOND., PHYSICIAN TO THE NORTH-EASTERN HOSPITAL FOR CHILDREN; AND

THEODORE FISHER, M.D. LOND., M.R.C.P. LOND., ASSISTANT PHYSICIAY TO THE EAST LONDON HOSPITAL FOR CHILDREN.

OCCASIONALLY cases of death from cardiac disease are seen in the post-mortem room not only in adults but also in children in which the ordinary well-recognised morbid affections of the heart are absent. Although such cases are rare, at least in children, that they do not attract attention more often is no doubt due to the fact that the idea that even slight degrees of mitral regurgitation are sufficient to account for death is deeply sunken in the medical mind. An apical systolic murmur has been heard during life and after death deformity of the mitral cusps is looked for and not perhaps uncommonly found without sufficient reason. One often hears of the expression "thickened edge of mitral" as if the thickened edge were sufficient to account for death. The so-called thickened edge is frequently merely the normal thickening which is situated where interlacing of the fibres of the chordæ tendineæ takes place at their insertion into the mitral cusps. This is made perfectly clear on holding up the large mitral cusp against the light, when the course of the fibres of the chordæ tendinea between the layers of endocardium forming the cusp can be readily seen. Although, however, we have frequently seen this normal band of thickening considered to be evidence of disease it is needless to say that abnormal thickening may be present in the same situation. When thickening of the mitral valve occurs it affects the fibres of the chordæ tendineæ from their origin at the apices of the musculi papillares to their termination at the mitral ring. As might be expected, this thickening of the fibres of the chord tendineæ is most evident where the normal interlacing takes place-that is, at their insertion into the cusps of the mitral valve. Such a band of thickening cannot, however, interfere with the action of the valve. Should regurgitation be present it is generally mainly due to shortening of the chordæ tendineæ, which shortening prevents efficient closure of the cusps. Slight degrees of mitral regurgitation can, however, hardly account for death and certainly cannot explain considerable general dilatation of the heart.

In the case recorded below slight thickening of the mitral cusps of the character which we have indicated was present, but was not sufficient in degree to have interfered in any way with the action of the valve. Mitral regurgitation was present, but in this case it was secondary to dilatation of the orifice, not to shortening of the chordæ tendineæ. The following are brief notes.

A boy, aged eight years, was sent to the North-Eastern Hospital for Children on Sept. 10th, 1905, by Dr. John Spurway of Brondesbury to be admitted under the care of one of us (G. O.). One year previously the boy had suffered from slight "heart trouble," and four montbs before admission there had been swelling of the elbows, knees, and bands. On admission the cardiac impulse was in the left fifth interspace outside the nipple line. A systolic murmur was present at the apex and a

I A paper read before the Society for the Study of Disease in Children on Jall. 19th, 1906. 
reduplicated second sound over the pulmonary area. On Nov. 6th the liver was noted as being two inches below the costal margin. The cardiac dulness extended also over one inch to the right of the sternum. In addition to the systolic murmur at the apex a to-and-fro sound was heard at the base which Dr. Carpenter considered might be either endocardial o: pericardial. The pulse was 140. Some oedema of the legs was present. On the 30 th the basic murmur was still present and the pulse was still 140. The celema of the legs was less. On Dec. 11th it is interesting to note that although the boy was in other ways worse the cdema of the legs had disappeared. He died on Jan. 2nd, 1906.

At the necropsy the body was found to be wasted. There was no trace of odema of the legs. The heart was much dilated. It extended from the junction of the cartilages and ribs on the right side to one inch outside the nipple line on the left; it weighed $10 \frac{1}{2}$ ounces. The pericardium was perfectly healthy, except that a few small petechiæ were present over the back of the auricles. Nothing could be found to account for the basic murmur. The pulmonary and aortic valves were both competent to the water test and the cusps were free from thickening. The tricuspid orifice was much dilated; it admitted four fingers, but the cusps were healthy. The mitral orifice was also dilated; it admitted three fingers. The chordæ tendineæ were sligbtly thickened but not shortened. There was no deformity of either the large or the small flap. "Water-marking" of the interior of the left auricle showed that there had been regurgitation through the mitral orifice during life. The cardiac muscle was pale but to the naked eye there was nothing definitely abnormal. The liver extended three inches below the costal margin; on section it presented the characteristic nutmeg appearance. There was nothing noteworthy about any of the other organs except the lungs, which were dotted over with small circular petechiæ. Microscopical examination of the heart muscle showed a few fibres in which fatty degeneration was considerable and many others in which small granules were scattered throughout the fibres, but the amount of fatty degeneration was not greater than is frequently seen in death from almost any cause. There was little or no increase of interstitial tissue. The microscopical examination threw no light npon the nature of the hypertrophy and dilatation.

As has already been mentioned, the main morbid condition present was dilatation, associated with hypertrophy of the heart, and the question of the causation of this dilatation and hypertrophy presents itself for consideration, as it does in all cases in which valvular disease and general adhesion of the pericardium are absent. In adults there are several causes of such a morbid condition of the heart, but in children possibly almost the only cause is rheumatism. Symptoms of cardiac weakness appear to have occurred in this boy before swelling of the joints was noticed, yet the fact that rheumatism definitely had at one time been present strongly suggests that there had been also an earlier attack which had fallen mainly upon the heart.

'I'he idea; however, that rheumatism, apart from valvular disease and general adhesion of the pericardium, can cause enlargement of the heart may appear fanciful. Let us consider for a moment, however, the enlargement which occurs in association with pericarditis due to rheumatism. In such cases not only dilatation but hypertrophy of the heart may be remarkably rapid. We have seen pericarditis develop in a girl, aged 11 years, while under treatment for chorea and cause death within a fortnight, at the end of which time the heart was more than double the normal weight for a child of that age, and such an event, which was noticed many years ago by Dr. J. F. Goodhart, is by no means uncommon. No other disease but rheumatism produces such a rapid increase in weight of the heart. It may be said that such rapid increase of weight must be due to imbibition of fluid. That may be so, but the heart does not return to a more normal size when the inflammation of the pericardium has subsided. On the contrary, the hypertrophy is generally progressive and the enlargement may become so great that even a child 12 years of age may possess a heart weighing 30 ounces. Barnard, Sequeira, and others have given a simple explanation for the dilatation of the heart in pericarditis. They consider that the pericarditis causes softening of the fibrous pericardium, which yields and allows dilatation of the heart. Hypertrophy follows this dilatation. If, however, softening of the fibrous pericardium were the explanation of dilatation of the heart associated with pericarditis, the dilatation should occur not only in rheumatic pericarditis but in other forms of pericarditis. But in forms of pericarditis equally, if not more virulent, such as the suppurative pericarditis of pneumonia, or of pyæmia, little or no dilatation of the heart takes place. This absence of dilatation in suppurative pericarditis one of us (T. F.) has long pointed out in the post-mortem room and mentioned it in reply to Dr. J. H. Sequeira at a meeting of the Society for the Study of Disease in Children in October, 1900. It is interesting to note, however, that Dr. G. F. Still has since commented upon the same fact. ${ }^{2}$

Since the difference in degree of the dilatation of the heart which occurs in association with rheumatic pericarditis and in suppurative pericarditis is very great, it seems clear that the dilatation rests upon no such simple causation as yielding of the fibrous pericardium. It depends, we believe, upon something more subtle, upon a poisoning of the hear which affects it chiefly in this way during the growing period of life. After the age of 20 years rheumatic pericarditis causes little or no dilatation of the heart. Allowing, however, that the enlargement of the heart is due to rheumatic poisoning, it is nevertheless true that such enlargement is rarely seen to follow rheumatism unless pericarditis has been present. But this is not surprising. Pericarditis is no doubt, an evidence of the most intense form of rheumatic infection of the heart, and to get infection which attacks the cardiac muscle while the pericardium escapes can hardly be expected to be common. It must also be remembered that some general cardiac hypertrophy is not uncommon in mitral stenosis. To explain hypertrophy of the left ventricle on mechanical grounds in mitral stenosis is not easy. It seems far more reasonable to allow that the hypertrophy is the result of some interference with the nutrition of the cardiac wall by the rheumatic poison. But however that may be, cases are undoubtedly to be seen from time to time of enlargement of the heart without valvular disease and without general adhesion of the pericardium in children who have suffered from rheumatism, and it is reasonable, in the absence of evidence of other causation, to attribute that enlargement to the rheumatism.

\section{OSSIFICATION OF THE FONTANELLES AND CLOSURE OF SUTURES AT BIRTH-A CAUSE OF DIFFI- CULT DELIVERY.}

BX T. LEAHY-LYNCH, L.R.C.P., L.R.C.S.\& L.M. EDIN., L.F.P.S. GLASG.

A PRIMIIPARA, aged 33 years, with vertex presentation in the first position, who was in labour for the usual number of hours, completed the first stage normally. I ruptured the membranes and left the patient a reasonable time to complete the second stage, but she exhibited failing strength and asked for my help. She was very nervous, so I determined to send for my partner, Mr. R. J. Mackay, to give an anæsthetic and to deliver her with forceps. She was got well under anæsthesia and the forceps was applied, but the handles were separated when the instrument was locked. Delivery was much more difficult and took longer than had been anticipated. For this I endeavoured to find a cause. The third stage over, I examined the baby's head; there were no moulding, no overlapping of the parietals over the frontal and occipital bones, and no overlapping of the parietal bones themselves ; there was no trace of a posterior fontanelle or of those at the anterior inferior angles of the parietals ; there was a mere depression over the anterior fontanelle or bregma; the sagittal suture was closed as well as the frontal, the coronal, and the lambdoid. In fact, ossification was complete in the fontanelles and sutures. The child was a healthy male, 21 inches in length, and weighing eight and a half pounds. No hydrocephalus was present. The blade of the forceps marked the infant slightly over the left mastoid region. The mother displayed sym. ptoms of puerperal insanity on the third day. She rambled, wanted to get out of bed, looked strange, buried her head in the pillow, took little notice of her surroundings, would 